\title{
SELF DISCLOSURE GENERASI Z DI TWITTER
}

\author{
Ajeng Prima Dewi ${ }^{1}$, Santi Delliana ${ }^{2}$ \\ 1,2IImu Komunikasi, Fakultas Industri Kreatif, Institut Teknologi dan Bisnis Kalbis
}

Naskah diterima tanggal 17-12-2019, direvisi tanggal 27-12-2019, disetujui tanggal 20-01-2020

\begin{abstract}
Abstrak. Pergeseran bentuk komunikasi antar individu melalui media sosial merupakan kajian yang menarik karena ruang tersebut memberikan tempat untuk mengekspresikan dirinya dan mengungkapkan pemikirannya. Namun tidak semua orang dapat memiliki keberanian ataupun kemampuan untuk melakukan pengungkapan diri atau self disclosure. Penelitian ini mengkaji bagaimana bentuk pengungkapan diri remaja generasi $Z$ melalui media twitter. Metode penelitian yang digunakan adalah metode kualitatif. Self Disclosure pada Media Sosial Twitter berbentuk emosi, kegundahaan, pemikiran, dan kesedihan dimana informan merasa lega dengan adanya dukungan atau support sebagai bentuk reply. Adanya kepercayaan yang terjalin dan juga sudah mengenal satu sama lain atara dirinya dan kawan-kawan sehingga merasa aman karena berada dalam frekuensi yang sama. Topik pengungkapan diri dibatasi, sehingga tidak memojokkan orang lain dna menjatuhkan nama orang lain.
\end{abstract}

Kata kunci: pengungkapan diri, remaja, generasi Z, twitter.

\begin{abstract}
The shift in the form of communication between individuals through social media is an interesting study because the space provides a place to express themselves and express their thoughts. But not everyone can have the courage or the ability to do self-disclosure. This study examines how the self-disclosure of adolescent generation $Z$ through twitter. The research method used is a qualitative method. Self Disclosure on Twitter Social Media takes the form of emotions, anxiety, thoughts, and sadness where the informant feels relieved by the support or support as a form of reply. There is a trust that is established and also knows each other between himself and his friends so that they feel safe because they are on the same frequency. The topic of self-disclosure is limited, so that it does not discredit others by dropping other people's names.
\end{abstract}

Keywords: self-disclosure, adolescents, generation Z, twitter. 


\section{PENDAHULUAN}

Pergeseran bentuk komunikasi antar individu melalui media sosial merupakan kajian yang menarik. Media sosial telah menjadi fenomena baru yang disukai oleh banyak orang. Ruang tersebut memberikan tempat untuk mengekspresikan dirinya dan mengungkapkan pemikirannya. Ekpresi emosi dan pemikiran bisa dalam bentuk pesan personal maupun yang dapat melibatkan banyak orang. Bentuk pengekspresian inilah yang disebut dengan pengungkapan diri atau self disclosure.

Menurut We Are Social, penggunaan media sosial di Indonesia per januari 2019 adalah sebanyak $55,65 \%$ dari penduduk Indonesia atau 150 juta jiwa. Rata-rata setiap hari untuk menggunakan media sosial melalui perangkat apapun di Indonesia yaitu 3 jam, 26 menit (Hootsuite.com). Sementara itu, menurut Kementrian Komunikasi dan Informatika (Kemkominfo) mengungkapkan bahwa Indonesia menempati peringkat 5 pengguna Twitter terbesar di dunia dan berdasarkan PT Bakrie Telecom, memiliki 19,5 juta pengguna di Indonesia dari total 500 juta pengguna global.

Twitter merupakan media sosial yang berbasiskan kata-kata dengan maksimal 280 karakter per-tweetnya. Twitter lebih fokus kepada tulisan-tulisan bukan keindahan visual sebagai bentuk ungkapan ekspresi tanpa harus 'berdandan' sebaik mungkin dengan background yang harus ditata sedemikian rupa untuk mendapatkan estetika didalamnya. Oleh karenanya tidak ada ke khawatiran mengenai estetika hal melalui foto ataupun video.

Penelitian ini hanya terbatas pada remaja akhir yang merupakan generasi $Z$ aktif dalam bersosial media dan berinternet,yaitu usia 19-22 tahun (Abidin, 2009: 10). Kelompok generasi Z yang merupakan remaja kelahiran tahun 1995 - 2010 (Badan Pusat Statistik, 2018: 15). Mereka memiliki persentase 91\% untuk usia 15-19 tahun dan 88,5\% untuk usia 20-24 tahun sebagai pengguna aktif internet menurut APJII (Asosiasi Penyelenggara Jasa Internet Indonesia).

Teori yang digunakan dalam penelitian ini adalah Johari Window atau jendela Johari. Teori ini menyatakan bahwa pengungkapan diri atau self disclosure dapat dilihat melalui empat bingkai yaitu daerah publik, daerah buta, daerah tersembunyi, dan juga daerah yang tidak disadari. Bingkai-bingkai tersebut juga dapat bergeser sesuai dengan pengungkapan diri yang dilakukan. Pergeseran fenomena tersbut juga dilihat dari konsep pengungkapan diri dari Devito yang didalamnya mencakup imbalan, faktor-faktor yang mempengaruhi pengungkapan diri, bahaya pengungkapan diri, dan juga pedoman pengungkapan diri.

Namun demikian tidak semua orang dapat memiliki keberanian ataupun kemampuan untuk melakukan pengungkapan diri atau self disclosure. Apa bentuk pengungkapan diri yang diutarakan, apa yang mereka dapatkan dari melakukan pengungkapan diri atau self disclosure tersebut dan bagaimana jika mereka dihadapkan dengan penolakan-penolakan yang ada ketika mereka melakukan pengungkapan diri?Merujuk pada hal tersebut, penelitian ini akan mengkaji bagaimana self disclosure (pengungkapan diri) remaja generasi $Z$ di media sosial Twitter?

\section{METODE PENELITIAN}

Penelitian ini menggunakan pendekatan kualitatif. Menurut Creswell (dalam Emzir, 2012: 1-2) penelitian kualitatif adalah penelitian yang bertumpuan kepada sumber-sumber informasi tetapi membawa ide-ide yang sama. Secara lebih spesifik, bagaimana pengungkapan dapat terjadi, bagaimana setiap individu bersikap, melakukan pengungkapan diri, maupun menerima pengungkapan diri orang lain yang memiliki persepsi dan juga caranya masing-masing untuk mengungkapkan diri sehingga mereka dapat melepaskan beban pikiran atas kondisi yang sedang dialaminya.

Data dalam penelitian diperoleh dengan melakukan wawancara, observasi, dan studi dokumentasi. Teknik pemilihan informan adalah teknik purposive sampling, yaitu dilakukan secara sengaja berdasarkan kriteria yang telah peneliti tentukan dan juga ditetapkan berdasarkan isi dan tujuan yang ingin dicapai dalam penelitian. Kriteria informan penelitian, yaitu a) Para remaja akhir yang merupakan generasi $Z$ (usia 19-22 tahun), b) pengguna aktif media sosial Twitter, c)Mer kerap terlihat melakukan pengungkapan diri si Twitter, dan d) 
bersedia di wawancara dan bersedia bentuk pengungkapan dirinya dimasukkan kedalam penelitian. Data yang diperoleh akan dianalisis dengan tiga tahapan, yaitu reduksi data, analisi data, dan verifikasi data.

\section{HASIL DAN PEMBAHASAN}

Berdasarkan hasil penelitian diketahui bahwa informan memilih untuk melakukan self disclosure karena di Twitter dirinya dapat menjadi pribadi yang ekspresif dibandingkan dengan menggunakan media sosial lain yang menurutnya lebih mementingkan visual atau gambar untuk mengunggah sesuatu hal.

"Kenapa tadi Twitter ya? Kalo Twitter itu kan bisasanya kalo misalnya bosen atau mengungkapkan diri berkeluh-kesah gitu kan lebih ekspresif tuh dari tulisan. Kalo lagi curhat lagi kesel gamungkin cuma ngasih gambar gitu kan.. kalo si Twitter tuh enaknya bisa secara gamblang mengekspresikan 'aduh gua lagi pusing nih, aduh macet nih' gitu-gitu sih"

Informan Femy memberikan anggapan bahwa pengguna akun Twitter lebih pintar, open minded, dan juga lucu. Mereka cenderung lebih menjadi dirinya sendiri dan dirinya menganggap dengan la menjadi dirinya sendiri sehingga dirinya merasa cemas jika didapatkan pengikut yang tidak dikenalnya nmengikuti (follow) dirinya karena menurutnya dalam Twitter ini hanya terdapat orang-orang yang dekat dengan dirinya sehingga jika terdapat seseorang yang la rasa tidak dikenalinya dirinya dapat menjadi ceman dan juga takut karena merasa isi tweet yang ada dalam akun Twitternya tidak boleh diketahui oleh banyak orang selain kerabat dekatnya.

"Kalo menurut Femy anak-anak Twitter tuh lebih pinter-pinter gitu loh lebih melek dan lucu. Mereka juga cenderung jadi dirinya sendiri aja, kalo di Twitter orang-orang follow kita malah takut"

Adapun bentuk dari pengungkapan diri yang dilakukan oleh remaja biasanya adalah halhal yang sedang dirasakannya yang tidak bisa dikatakannya kepada orang lain secara langsung.

"Kalo gue jenis pengungkapannya tuh lebih ke keseharian sih ya gak terlalu condong ke marah-marah doang atau gimana, tapi lebih sering curhat sih tentang hati atau kegundahan sih kalo gue soalnya kan gua tipe orang yang gabisa langsung kayak ngobrol gitu loh jadi lebih baik kayak yaudahlah gue ketik ajalah kan orang-orang belum tentu tahu itu karna apa kan? Jadi gabisa langsung 'oh ini dia pasti lagi gini gini gini..' cuma dari tulisan doang gitu loh. Jadi, gua lebih baik kaya gitu curhatnya."

Pengungkapan diri di twitter tidak hanya berupa emosi tetapi juga kegundahaan, pemikiran, dan kesedihan. Pengungkapan diri yang bervariasi dari para informan dikarenakan pendapat dan juga cara pandang seseorang tidak bisa disama-ratakan satu dengan yang lainnya dalam bentuk pengungkapan diri yang mereka lakukan dalam upaya guna mencurahkan dan mengekspresikan segala rasa yang mereka rasakan dalam suatu bentuk kata-kata dan juga tulisan yang dilontarkan berupa tweet sehingga mereka merasakan kelegaan atau plong karena telah bisa mengungkapkannya.

"Manfaatnya buat gue, kalo gue tuh lebih ngerasa plong, terus senengnya kalo di Twitter itu jadi lebih banyak interaksi juga gitu. Banyak yang reply terus gua jadi ngobrol kayak gitu kan. Gua juga pernah di retweet Bernard Batubara (penulis buku) seneng banget gue."

Pengungkapan diri yang para informan lontarkan di Twitter merupakan sebuah bentuk dimana mereka ingin meringankan beban-beban yang mereka topang dalam pikirannya menjadi sebuah tweet yang mereka harapkan dapat hilang atau setidaknya lebih ringan dan 
juga guna mendapatkan dukungan dari kawan-kawan cyber-nya yang merupakan followers atau pengikutnya di Twitter.

Telah dijelaskan mengapa mereka memilih Twitter dibandingkan media sosial lainnya untuk pengungkapan diri dikarenakan mereka rasa semua orang masih asyik dengan media sosial lain sehingga banyak dari mereka yang melupakan Twitter juga pernah ada. Dikarenakan Twitter ditinggalkan, mereka merasa bahwa Twitter merupakan tempat atau wadah yang cocok untuknya mengungkapkan diri dikarenakan sedikit orang yang akan melihat bentuk pengungkapan dirinya.

Twitter menjadi tempat pengungkapan diri bagi para informan dikarenakan Twitter merupakan media sosial yang cocok untuk mencurahkan apa yang mereka ingin utarakan melalui kata-kata dan juga tulisan tanpa embel-embel harus menaruh atau melampirkan foto atau video yang bagus secara visual.

\section{Daerah Publik (Public Area)}

Berdasarkan hasil penelitian diketahui bahwa terdapat Daerah Publik (public area) terbuka pada remaja generasi $z$ yang menjadi informan dikarenakan adanya bentuk pengungkapan diri yang dilakukan para informan. Dari hasil penelitian yang dilakukan oleh para informan didapatkan hasil bahwa para informan mengutarkan atau melontarkan bentuk pengungkapan diri berupa emosi, kegundahaan, pemikiran, dan kesedihan kedalam bentuk tweet yang akhirnya disebarkan dan juga dapat dilihat oleh pengikutnya atau followers dan juga following mereka di Twitter. Pengungkapan diri inilah yang membuat bingkai daerah publik atau public area diperbesar. Dari pembesaran daerah publik ini, mengartikan bahwa seseorang yang terbuka terhadap orang lain 'saya tahu, orang lain tahu'.

Pergeseran bingkai $A$ ini juga didukung oleh aspek-aspek menurut DeVito mengenai pengungkapan diri yang terdiri dari Imbalan, atau manfaat yang didapatkan dari bentuk pengungkapan diri dari para informan. Imbalannya adalah adanya rasa lega atau plong yang dirasakan oleh para informan sehingga beban yang mereka pikirkan dapat berkurang. DeVito (2011: 67-69) mengungkapkan terdapat poin-pion dari imbalan atau manfaat itu sendiri yaitu

\section{Pengetahuan Diri.}

Bentuk pengungkapan diri ini terbilang penting dalam bentuk hubungan konseling dan juga psikoterapi dan mengatakan bahwa seseorang juga membutuhkan bantuan seperti itu karena mereka ini tidak pernah dan tidak berani untuk mengungkapkan dirinya kepada orang lain (DeVito, 2011: 67). Menurut hasil penelitian pengetahuan diri ini terlihat pada bentuk bahwa sesungguhnya para informan merasa senang ketika mendapatkan dukungan dari kawan Twitternya sehingga dirinya merasa termotivasi atas kondisi yang sedang dihadapinya karena sesungguhnya dengan melakukan pengungkapan diri ini seseorang ingin merasakan adanya penerimaan dari lingkungannya terhadap kondisinya.

Selanjutnya adalah Kemampuan Mengatasi Kesulitan. Kesulitan yang biasanya dirasakan seseorang untuk dapat mengungkapkan diri adalah rasa takut mereka tidak diterima oleh lingkungannya mengenai hal tertentu yang mereka rahasiakan. Bentuk ini merupakan suatu bentuk dasar dari penolakan. Maka dengan mengungkapkan dirinya, seseorang ingin merasa didukung bukan ditolak (DeVito, 2011: 67-68). Menurut hasil penelitian yang dilakukan jawaban yang didapatkan mengacu kepada poin sebelumnya yaitu pengetahuan diri dimana seseorang ingin merasa didukung. Sama halnya dengan poin ini dimana para informan ingin adanya dukungan terhadap dirinya sehingga dirinya dapat meringankan beban pikirannya

Aspek ketiga adalah Efisiensi Komunikasi. Pengungkapan diri ini merupakan kondisi penting untuk mengenal orang lain. Lain hal terjadi apabila seseorang tidak pernah mengungkapkan dirinya maka kita juga tidak akan memahami orang itu sebagai pribadi yang utuh (DeVito 2011: 69). Menurut hasil penelitian didapatkan hasil bahwa para informan lebih nyaman untuk mengungkapkan diri kepada mereka yang juga mengungkapkan diri dan mereka yang sudah dikenalinya terlebih dahulu sehingga timbul rasa kepercayaan sehingga kedua belah pihak merasa nyaman untuk dapat melakukan pengungkapan diri. 
Keempat berupa Kedalaman Hubungan. Pengungkapan diri juga bentuk dari mempercayai dan menghargai seseorang tersebut. Apakah kita cukup peduli dengan mereka sehingga kita juga dapat mengungkapkan diri kita sendiri kepada mereka. Apabila hubungan ini terjadi maka pembukaan diri akan membentuk suatu hubungan yang jujur dan juga terbuka (DeVito 2011: 69). Menurut hasil penelitian yang didapatkan bahwa para informan memilih untuk melakukan pengungkapan diri kepada mereka yang sudah mengenalnya sehingga mereka membatasi orang-orang yang tidak dikenalinya untuk tidak memasuki akun Twitter mereka karena dengan batasan tersebut para informan ingin meminimalisir kemungkinan adanya penolakan yang tidak diinginkannya.

Adapun faktor-faktor yang Mempengaruhi Pengungkapan Diri menurut Devito (2011: 6567) adalah Perasaan Menyukai. Kita cenderung akan mengungkapkan diri kita kepada orang yang kita sukai namun juga kita dapat menyukai orang tersebut apabila la atau kita mengungkapkan diri kepadanya sehingga muncul rasa percaya dan nyaman untuk dapat mengungkapkan diri kita (DeVito, 2011:65). Dari hasil penelitian didapatkan hasil bahwa para informan lebih cenderung untuk melakukan pengungkapan diri kepada mereka yang mereka sukai dan juga cintai karena adanya rasa kepercayaan dan juga nyaman sehingga mereka merasa jauh dari rasa penolakan tersebut.

Selain itu adalah Efek Diadik. Pengungkapan diri akan terjadi apabila seseorang juga mengungkapkan dirinya kepada kita sehingga menimbulkan rasa lebih aman dan juga percaya (DeVito, 2011:66). Dari hasil penelitian yang didapatkan bahwa telah dibahas beberapa kali sebelumnya bahwa rasa percaya merupakan salah satu hal penting untuk melakukan pengungkapan diri. Dalam hasil penelitian juga didapatkan bahwa para informan merasa berada di dalam tempat yang sama karena kawan-kawan Twitternya juga melakukan hal yang sama seperti yang dilakukannya (pengungkapan diri). Sehingga mereka merasa berada dalam satu frekuensi dengan kawan-kawan Twitternya.

Namun demikian ditemukan bahaya dari pengungkapan diri yaitu Penolakan Pribadi dan Sosial. Seseorang biasanya melakukan pengungkapan diri kepada seseorang yang dipercayainya sehingga merasa aman untuk mengutarakan hal mengenai dirinya. Namun tidak dipungkiri bahwa pihak-pihak yang kita anggap dekat dan kita percaya juga kadang bertolak belakang dengan pendapat kita (DeVito, 2018: 69).

Berdasarkan hasil penelitian yang dilakukan didapatkan hasil bahwa apabila para informan dihadapkan oleh penolakan mereka akan menerimanya dikarenakan menurut mereka perbedaan pendapat merupakan hal yang wajar selama penolakan tersebut tidak keras atau sangat memojokkan (offensive) karena seorang terdekat sekalipun dapat melakukan penolakan tetapi dengan adanya pengenalan antara satu dengan yang lainnya membuat penolakan lebih halus sehingga tidak terkesan memojokkan.

Kedua adalah Kesulitan Intrapribadi. Kesulitan ini akan terjadi apabila respon atau reaksi dari orang lain tidak sesuai dengan apa yang diharapkan, kesulitan intrapribadi tentu dapat terjadi apabila seseorang justru ditolak dan bukan didukung atau bahkan apabila orangtua justru mencemooh dibandingkan membela (Devito, 2011: 70). Menurut hasil penelitian yang didapatkan dari kesulitan intrapribadi adalah ketakutan adanya penolakan. Namun, hal ini dibatasi oleh para informan dengan melakukan pengungkapan diri yang tidak bersifat terlalu pribadi yang mengartikan dirinya berada dalam zona yang aman karena berada dalam lingkup yang dipercayainya.

Selain manfaat dan bahaya, DeVito, 2011: 70-71 menjelaskan Pedoman Pengungkapan Diri, yaitu Kepatutan Pengungkapan Diri. Disarankan sebaiknya kita tidak mengungkapkan sesuatu yang bersifat terlalu pribadi kepada orang lain yang tidak kita percayai atau tidak akrab pada tahap awal hubungan atau perkenalan (DeVito, 2011: 70-71).

Dari hasil penelitian yang didapatkan para informan memilih membatasi dirinya untuk tidak mengungkapkan hal-hal yang bersifat sangat pribadi. Para informan juga mengungkapkan bahwa mereka tidak memasukkan orang-orang yang mereka anggap tidak dikenalinya dan juga tidak dipercayainya. Maka dari itu para informan membuat Twitter mereka berisikan orangorang yang dipercayainya sehingga mereka dapat melakukan pengungkapan diri. 


\section{Daerah Tersembunyi}

Daerah Tersembunyi memiliki porsi yang cukup besar dibandingkan dengan daerah buta dikarenakan menurut hasil penelitian yang telah dilakukan oleh peneliti, para informan tetap menjaga daerah tersembunyinya yang menurut mereka merupakan hal privasi yang tidak harus diketahui oleh orang lain. Yang dimana dasar yang dimiliki oleh daerah tersembunyi adalah 'saya tahu, orang lain tidak tahu' merupakan dimana mereka masih menjaga dan menutup dirinya untuk membuka hal-hal yang menurut mereka sensitif dan juga privasi untuk di lontarkan dalam bentuk tweet.

Hal-hal privasi yang disembunyikan oleh para informan menurut observasi dan juga wawancara yang dilakukan adalah masalah keluarga. Mereka cenderung memilih untuk tidak memberikan pengungkapan mengenai keluarga karena menurut mereka keluarga merupakan hal yang sangat sensitif dan juga harus memili kedekatan dan juga kepercayaan yang lebih untuk mereka dapat mengungkapkan diri mereka untuk masalah keluarga.

Pergeseran daerah tersembunyi atau hidden area juga dipengaruhi oleh Besar Kelompok. Dipercaya dengan satu pendengar maka pengungkapan diri akan terjadi lebih mudah. Informasi atau pesan akan diteruskan apabila memungkinkan dan tidak diteruskan apabila tidak memungkinkan (DeVito, 2011: 65). Menurut hasil penelitian yang didapatkan bahwa para informan melakukan pengungkapan diri berupa tweet yang dimana para informan menjadikannya sebagai pembukaan terhadap kawan Twitternya.

Apabila pesan dibalas melalui reply dan pesan diteruskan dalam pesan pribadi Twitter atau direct message (DM) maka yang mengetahui lebih dalam mengenai pengungkapan diri tersebut hanya pemilik akun dan orang yang diajaknya untuk berkomunikasi sehingga lanjutan pengungkapan diri menjadi rahasia.

Faktor lain adalah topic. Seseorang akan lebih cenderung mengungkapkan diri mengenai suatu hal yang tidak bersifat sangat pribadi. Maka dari itu seseorang akan lebih nyaman dan less pressure untuk mengungkapkan informasi mengenai pekerjaan atau hobinya dibandingkan mengenai hal yang lebih bersifat privasi (DeVito, 2011: 67). Dari hasil penelitian yang didapatkan bahwa semua informan mengatakan hal yang sangat privasi yang tidak dapat dilontarkan sebagai bentuk pengungkapan diri adalah 'keluarga' karena menurut para informan keluarga merupakan hal yang sangat sensitif dan disisi lain mereka tidak ingin membuat keluarganya dipandang tidak sepantasnya oleh orang lain yang tidak mengetahui masalah keluarganya.

Pengungkapan diri haruslah didorong oleh rasa berkepentingan terhadap hubungan tersebut dengan orang lain yang terlibat dan dirinya sendiri. Sementara orang melakukan pengungkapan diri untuk menyakiti pendengar (DeVito, 2011: 71). Dari hasil penelitian yang didapatkan bahwa disini para informan juga kerap melakukan pengungkapan diri. Namun para informan juga melakukan bentuk pengungkapan berupa sindiran terhadap suatu pihak melalui tweetnya. Sindiran ini berperan untuk menggeser daerah tersembunyi dikarenakan sindiran tersebut dibuat menjadi general atau luas. Sindiran ini tidak langsung menyudutkan atau menyebutkan nama ataupun inisial sehingga tidak diketahui bentuk pengungkapan tersebut ditujukan kemana dan siapa.

\section{Daerah yang Tidak Disadari}

Daerah yang tidak disadari memiliki porsi yang lebih besar sedikit dibandingkan dengan daerah buta dikarenakan dalam hasil penelitian masih didapatkan bahwa terdapat hal yang mempengaruhi daerah yang tidak disadari masih terbuka. Disini kedua belah pihak cukup banyak mengetahui dirinya dan juga orang lain yang merupakan followers-nya atau kawan cyber-nya dikarenakan pengungkapan diri yang ada sehingga bingkai ini diperkecil dan dengan alasan tersebut pula penerimaan pesan dan juga pemberi pesan sama-sama mengenali lebih banyak antara satu dengan yang lainnya sehingga porsi 'saya tidak tahu, orang lain tidak tahu' lebih kecil dibandingkan dengan daerah terbuka dan juga daerah tersembunyi.

Berdasarkan hasil penelitian mengenai self disclosure atau pengungkapan diri, bingkai ini didukung oleh konsep DeVito, yaitu Kompetensi. Orang yang kompeten cenderung lebih banyak melakukan pengungkapan diri dibandingkan dengan orang yang tidak kompeten 
(DeVito, 2011: 66). Dari hasil penelitian yang dilakukan didapatkan hasil bahwa bentuk kompetensi seseorang dalam melakukan pengungkapan diri tidak ditemukan dikarenakan tidak ada aspek-aspek yang merujuk kepada bagaimana seseorang dapat dikatakan sebagai seorang yang berkompeten. Karena untuk melihat seseorang yang berkompeten tidak bisa hanya melihat dari bentuk pengungkapan dirinya.

Akibat pengungkapan diri dapat berupa Kerugian Material. Adakalanya pengungkapan diri dapat menimbukan kerugian material. Sebagai contoh terjadi pada pihak-pihak yang berhubungan dengan orang banyak seperti politisi yang melakukan kampanye habis-habisan untuk menadapatkan simpati masyarakat sehingga masyarakat memilihnya namun pada pemilihan la tidak menang (DeVito, 2011: 70). Dari hasil penelitian yang dilakukan tidak didapatkannya hasil kerugian material dikarenakan para informan menggunakan Twitter bukan sebagai media komersil dimana para informan tidak mencari keuntungan material ataupun vote massa untuk melakukan hal yang berhubungan dengan kampanye ataupun khalayak luas.

\section{SIMPULAN}

Self Disclosure pada Media Sosial Twitter berbentuk emosi, kegundahaan, pemikiran, dan kesedihan dimana informan merasa lega dengan adanya dukungan atau support sebagai bentuk reply. Adanya kepercayaan yang terjalin dan juga sudah mengenal satu sama lain atara dirinya dan kawan-kawan sehingga merasa aman karena berada dalam frekuensi yang sama. Topik pengungkapan diri dibatasi, sehingga tidak memojokkan orang lain dan menjatuhkan nama orang lain.

\section{DAFTAR PUSTAKA}

Abidin, Yusuf. (2009). Guru dan Pembelajaran Bermutu. Bandung: Rizqi Press.

Akbar, P.S. \& Usman, H. (2011). Metodologi Penelitian Sosial. Jakarta: Bumi Aksara.

Arikunto. (2010). Prosedur Penelitian Suatu Pendekatan Praktik. Jakarta: Rineka Cipta.

Asosiasi Penyelenggara Jasa Internet Indonesia. (2018). Penetrasi \% Profil Perilaku Pengguna Internet Indoensia. Polling Indonesia.

Badan Pusat Statistik. (2018). Profil Generasi Milenial Indonesia. Kementrian Pemberdayaan Perempuan dan Perlindungan Anak.

Devito, A. J. (2011). Komunikasi Antarmanusia Edisi Kelima. Tangerang selatan: Karisma Publishing Group.

Emzir. (2012). Metodologi Penelitian Kualitatif Analisis Data. Jakarta: Rajawali Pers.

Gunawan, Imam. (2013). Metode Penelitian Kualitatif: Teori dan Praktik. Jakarta: PT Bumi Aksara.

Rakhmat, Jalaludin. (2013). Psikologi Komunikasi. Bandung: Remaja Rosda Karya.

Satori, D \& Aan, K. (2014). Metodologi Penelitian Kualitatif. Bandung: ALFABETA.

Sugiyono. (2013). Metode Penelitian Kualitatif dan R\&D. Bandung: ALFABETA.

Wilcox, Lynn. (2018). Psikologi Kepribadian. Yogyakarta: IRCiSoD.

\section{Artikel Jurnal:}

Ardiyanti. N. \& Sagiyanto. Asriyani. "Self Dsisclosure melalui Media Sosial Instagram (Studi Kasus pada Anggota Galeri Quote)". Nyimak Journal of Communication. Vol. 2 (April 2018). Pp. 81-94.

Delliana, S., \& Mamby, A. (2019). Digital Labor: Between the Innovation or Exploitation. Journal of Advanced Research in Dynamical and Control Systems, 11(5), 623-630. Retrieved from https://www.jardcs.org/abstract.php?id=1980

Rahmat. S.T. "Pola Asuh yang Efektif Untuk Mendidik Anak Di Era Digital". Jurnal Pendidikan dan Kebudayaan Missio, Vol 10, (Juni 2018). HIm. 137-273.

Sari. D.P. "Pembukaan Diri Secara Online (Online Self Disclosure) Remaja Generasi Z". Jurnal Penelitian, Vol. 22 (Mei, 2018). hal. 13-19.

Tamara. S. "Self Disclosure Lesbian Kepada Ayah dan Ibu Mengenai Orientasi Seksualnya". Jurnal E-Komunikasi, Vol. 4 (2016) 


\section{Artikel Internet:}

"Kominfo: Pengguna Internet di Indonesia 63 Juta Orang". www.kominfo.go.id/content/detail/3415/kominfo-pengguna-internet-di-indonesia-63-jutaorang/0/berita_satker (diakses pada 21 Maret 2019).

Maalouli, Carla El. "The evolution of the Twitter brand". www.adigitalboom.com/evolution-twitterbrand/ (diakses pada 16 Juni 2019).

Parrish, Adam."Logo histories: Twitter". www.creativefreedom.co.uk/icon-designers-blog/twitterlogo-history/ (diakses pada 16 Juni 2016).

"The Global State of Digital in 2019 Report". www.hootsuite.com/pages/digital-in-2019 (diakses pada 21 Maret 2019).

Wolan, Christian. "The Real Story of Twitter". www.forbes.com/sites/christianwolan/2011/04/14/the-real-story-of-twitter/\#30992d0b66af (diakses pada 23 Mei 2019).

\section{Skripsi/Tesis:}

Ningsih, Widiyana (2015). "Self Disclosure Pada Media Sosial (Studi Deskriptif Pada Media Sosial Anonim LegaTalk)". Skripsi, Fakultas IImu Sosial dan IImu Politik Universitas Sultan Ageng Tirtayasa, Banten. 